\title{
ROMANIAN $A$ CINSTI IN THE LIGHT OF SOME ROMANIAN-SLAVIC CONTACTS
}

https://doi.org/10.52603/rec.2021.29.14

\section{Rezumat \\ Cuvântul românesc $a$ cinsti în lumina unor contacte româno-slave}

Pornind de la comparaţia dintre cuvântul ucrainean частувати ,a trata' și românescul a cinsti, a trata (cu vin), a bea vin, se consideră un grup de împrumuturi slave cu /n/ epentetic în limba română, căreia îi aparține și a cin$s t i$. Interpretând corpul de fapte disponibil, putem presupune că convergență semantică dintre cuvintele честь и угощение a apărut în perioada slavică timpurie. Cuvântul românesc a cinsti este un argument important pentru datarea timpurie a apariției acestei convergențe semantice. Așadar, cuvântul ucrainean частуватu, ca și cuvântul polonez częstowac, apar independent unul de celălalt, la fel ca și de cuvântul românesc a cinsti. Cuvântul românesc a cinsti, ca și, în general, grupul menționat de împrumuturi slave cu /n/ epentetic în limba română, reprezintă un rezultat al contactelor timpurii ale limbii române cu un dialect (dialecte) slav vechi, pentru care era caracteristică tendința de a utiliza vocala nazală epentetică. $\mathrm{Cu}$ toate acestea, putem presupune că în graiurile ucrainene din zona Carpaţilor se pot găsi urme al acestui dialect slav vechi. În special, acestor urme ar putea fi atribuite variante dialectale ucrainene чандрий, шандрий, чендрий 'generos', ca şi un alt cuvânt dialectal, reflectat în graiul ucrainean din satul Bulăești: /мон|золетеи/ 'мусолить; впустую теребить'.

Cuvinte-cheie: slavi, români, împrumuturi lexicale, istorie etnică, dialectele ucrainene, Moldova, Bucovina.

\section{Резюме \\ Румынское $a$ cinsti в свете некоторых румыно-славянских контактов}

Рассматривается группа славянских заимствований с неэтимологическим /н/ в румынском языке, к которой и принадлежит a cinsti. Интерпретируя имеющуюся совокупность фактов, можно предположить, что семантическое сближение между честь и угощсение возникло еще на позднепраславянском уровне. Румынское a cinsti, представляющее собой раннее славянское заимствование, также со всей очевидностью свидетельствует об еще позднепраславянском времени возникновения вышеозначенной семантической связи. Соответственно, украинское частувати и польское czestowac - возникают в целом самостоятельно друг от друга, равно как и от румынского a cinsti. Тогда как румынские a cinsti (и cinste), как и в целом группа славянских заимствований румынского языка с неэтимологическим звуком /н/, являются результатом ранних контактов румынского языка с неким позднепраславянским диалектом (или диалектами) - для которого была характерна тенденция широкого использования неэтимологических носовых гласных. Можно предположить, что в карпато-украинских говорах также нашли определенное отражение следы обозначенного позднепраславянского диалекта (диалектов). В частности, к таким следам, возможно, стоит отнести как украинские диалектные чандрий, шандрий, чендрий, так и диалектное (зафиксировано в украинском говоре с. Булэешть) / мон|золете / 'мусолить; впустую теребить'.

Ключевые слова: славяне, румыны, лексические заимствования, этническая история, украинские диалекты, Молдова, Буковина.

\section{Summary \\ Romanian a cinsti in the light of some Romanian-Slavic contacts}

A group of Slavic loanwords with epenthetic $/ \mathrm{n} /$ in the Romanian language, to which a cinsti belongs, is considered. Interpreting the existing set of facts, the author supposes that the semantic convergence between the Slaviс честь 'honour' and угощение 'treat' appeared as far back as the Late Slavic period. The Romanian a cinsti, which is an early Slavic borrowing, also clearly testifies Slavic origin of this semantic convergence. Accordingly, the Ukrainian yасmyватu and Polish częstowac appeared independently from each other, as well as from the Romanian $a$ cinsti. Whereas the Romanian a cinsti (and cinste), as well as the whole group of Slavic loanwords in the Romanian language with the epenthetic sound $/ \mathrm{n} /$, are the result of early contacts of the Romanian language with some late Slavic dialect (or dialects), which was characterized by a tendency of widespread epenthetic nasal vowels. We can suppose that some traces of this for-Slavic dialect (dialects) could also be found in the Carpathian Ukrainian dialects as well. In particular, such traces, perhaps, should include both the Ukrainian dialectal чандрий, шандрий, чендрий and another Ukrainian dialectal form, recorded in the Bulaesti village, /мон|золете ${ }^{\text {/ ' }}$ 'procrastinate; fiddling around in vain' (in Russian: 'мусолить; впустую теребить').

Key words: Slavs, Romanians, lexical loanwords, ethnic history, Ukrainian dialects, Moldova, Bukovina.

The starting point of the research was a word which exists in the dialect of the Ukrainians of Bulaesti village (Orhei district, Republic of Moldova; see for details: Романчук, Тащи 2010). This word, /ч'асту'шате to pour wine into glasses during a feast'; it is a variant of the common Ukrainian yастувати 'to treat' (ECYM 6: 284). The common opinion today is that the Ukrainian частувати had its origin from the Polish czesstowac (ECYM 6: 284; Brukner 1985: 78).

A closer look at these words provides the possibility to perceive some interesting facts. First, semantically the Bulaestian dialectal word has some differences 
comparing with the common Ukrainian word; the Bulaestian variant is used only in-a narrower meaning.

The Bulaestian variant differs (including phonetically) also from the variants, that exist in the Bukovinian and Hutsul Ukrainian dialects (both are closely related to the Bulaestian idiom). Thus, in the Hutsul dialect честувати means 'to treat; to respect' (ГГ 1997: 212). The difference of the Bukovinian dialect variants is even more significant: чiсmувати - 'to make gifts at a wedding' (СБГ 2005: 647); частувати, чістувати, частовання - with the same meaning (СБГ 2005: 637).

Besides the Ukrainian and Polish components of the issue, the Romanian language also presents extremely important data for discussion.

The Romanian language (including its Moldavian dialect as well) demonstrates that the verb a cinsti (and the noun cinste 'honesty; honor', are related to the mentioned verb) with a wide range of meanings, including the meaning closely related to the Bulaestian /ч'асту'шате 1 , as well as to the Bukovinian variants. Thus, a cinsti has the meaning (besides others) 'to drink (wine)' (in Romanian: „A bea o băutură alcoolică” (DEX); see also: MPC 1961: 721).

It is important to note here a that the noun cinstáş 'a person who makes gifts at a wedding' (DEX); is mentioned in Romanian dictionaries (marked: "regional, fixed in the Romanian dialects of Bukovina"). As we see, both semantically and by the region of fixation it addresses us to the Ukrainian dialects of Bukovina.

The verb a cinsti (as well as the noun cinste) by their origin belong to "Early Slavic" (that means: of the for-Slavic time) loanwords of the Romanian language (СДЕЛМ 1978: 488). And what deserves special emphasis here, the sound $/ \mathrm{n} /$ in a cinsti (as well as in the cinste) is non-etymological (i. e. epenthetic).

Thus, by the presence of epenthetic /n/, Romanian a cinsti (and cinste) are similar to the Polish czestowac, that has a secondary, non-etymological, nasal vowel, and derived from the earlier czestowac (Brukner 1985: 78).

Let us mention here that the Polish cześć 'honour' (Brukner 1985: 77), from which derived czestowac (and, respectively, czestowac), never got the secondary nasal vowel. So, it differs with the Romanian cinste 'honour'.

In my opinion, some other facts need to be considered. First, P. E. Hritsenko had analyzed in details the very interesting phenomenon when, as a result of Polish influence (according to P. E. Hritsenko's opinion), some words in the Ukrainian dialects demonstrate the appearance of epenthetic /n/ (or /m/) (Гриценко 1997); some examples of this process were found in the dialect of Bulaestian Ukrainians as well (Roman- chuk 2017). Thus, the Ukrainian yacmyвamu is an example of a kind of "anti-mainstream". And it is all the more surprising that the supposed Polish source, czestowac, had got the secondary nasal vowel.

Second, explaining the Ukrainian частувати, we should not forget about the very typical to the WestUkrainian dialects (especially in the Volyni region) feature as the transition of sounds /e/ to /a/ under certain conditions (Шевельов 2002: 199). Thus, Iu. Sheveliov [Yu. Shevelyov] considered the Ukrainian частувати as a result of this transition of /e/ to /a/; although he made a reservation: "if this word comes from $\check{c} b s t b$, but is not a phonetic adaption of the Polish czestowac - the last variant looks more probable" (Шевельов 2002: 198).

Third, besides the Czechs častovati and the Slovakian častovat' (both are also supposed to be polonisms (ECYM 6: 284)), we can see also the Serbian yacm 'honour', and, respectively, yаститu - similar to Polish, Ukrainian, Czech, and Slovakian meanings (ECYM 6: 284). It is clear, that we can't (and do not need) to explain Serbian words by Polish influence.

Thus, the semantic convergence between Slavic честь 'honour' and угощение 'treat' (including (and, probably, first of all) 'wine treat') appeared, as we can suppose, as back as in the Late for-Slavic (at least) period. This clearly follows,-already from the given Serbian data. And also from the fact, that in Old Russian language чьститu with the meaning 'to regale, to treat' existed in the second half of the XIV century A. D. (in 1378, in the "Teachings of Matthew, the Bishop of Sarai"). and namely in the context of 'wine treat' (Срезневский 1912: 1571). So, this Old Russian word is evidently not related to any Polish influence. Therefore, the facts considered above make us to doubt believe Polish as a source for the Ukrainian частувати.

Finally, the Romanian a cinsti is a key argument for Late Slavic origin of the semantic convergence between the Slavic честь 'honour' and угощуение 'treat'. The Romanian a cinsti (and cinste) is not a unique isolated phenomenon, but part of the group of Slavic loanwords with epenthetic / $\mathrm{n} /$ in the Romanian language.

Analyzing the data of the etymological dictionary of the Moldavian dialect of the Romanian language (СДЕЛМ 1978), I found the Romanian words of Slavic origin with epenthetic /n/ given below.

Let's start with a word cited by СДЕЛМ close to a cinsti, namely, with the word cinsteț - the name of the plant 'Salvia glutinosa' (according to: DEX). According to СДЕЛМ (Romanian dictionaries agree with СДЕЛМ here) "чинстец - is borrowed from the Ukrainian чистеųь (plants Draba verna, Gallium Mollugo, Orbus allus, <...>" (СДЕЛМ 1978: 488). 
The word чucmeu as a name for the variety of plants is known in all Slavic languages (ECYM 6: 283). The Polish language is not an exception here, as we have Polish czyściec 'Stachys L.'.

Second, according to etymological dictionaries (СДЕЛМ 1978: 148) the Romanian zbeng 'playfulness, agility' (MPC 1961: 232) has its origin in Serbo-Croatian збег 'asylum, refugee'; the sound /n/ in the Romanian word, consequently, is epenthetic. Let's mention especially that the meaning of the supposed Serbian source differs very significantly from the meaning of the Romanian word.

Third, let's consider the Romanian word a zmunci 'to snatch, to pull' (MPC 1961: 237). Romanian dictionaries, that differ from the dictionaries of the Moldavian dialect, give the variant without epenthetic /n/ as a basic one, a norm: a smuci (DEX). This word, a zmun$c i$, is also an "Early Slavic" loanword which derived from the for-Slavic съмыкати (СДЕЛМ 1978: 152), or, according to ECУM: (s)mykati 'to tear; to move', mъknoti 'to pull; to pluck; to push' (ECYM 3: 459).

Fourth, the Romanian a mânji 'to soil' (MPC 1961: $400)$ is an "Early Slavic" loanword also from мазати (СДЕЛМ 1978: 270: see also: ЕСУМ 3: 359).

Fifth, the Romanian a otânji 'to beat' (MPC 1961: 442) is borrowed from the Serbo-Croatian omy $\overline{\text { u, with }}$ the same meaning (ECYM 1978: 297).

Sixth, the Romanian word a scânci 'to whine' (MPC 1961: 585) is also an "Early Slavic" loanword (from Slavic skučiti (ECУM 5: 290)), the sound /n/ is epenthetic (СДЕЛМ 1978: 386).

Seventh, the Romanian word strung (the variant: strug). Modern dictionaries give the meaning 'lathe' (MPC 1961: 608). However, in the earlier times this word (which is also an "Early Slavic" loanword to Romanian (СДЕЛМ 1978: 408) derives from the for-Slavic strbgati (ЕCУM 5: 451)), and meant a more primitive tool for shaving wood.

Eighth, the Romanian sfrâncioc 'shrike' (MPC 1961: 627). It comes from Serbo-Croatian сврачак 'shrike', the sound /n/ is epenthetic (СДЕЛМ 1978: 413). (See also: ECYM 5: 356).

Ninth, the Romanian uncrop 'boiling water' (MPC 1961: 670). According to (СДЕЛМ 1978: 448), this word is an "Early Slavic" loanword (comes from for-Slavic *okrops, *ukrops (ECУM 4: 173)), the sound $/ \mathrm{n} /$ is epenthetic.

Tenth, the Romanian smântână 'sour cream' (MPC 1961: 589). According to (СДЕЛМ 1978: 389), this word is an Early Slavic loanword in the so called "Danubian Latin" (the "ancestor" of Romanian language); it comes from the for-Slavic *sümetana ( $<*$ sümetati 'to gather; to take off'). However, there is a continuous discussion concerning the origin of the Slavic cметана. The authors of ECYM dictionary, leaving to a large extent the question open, preferred another etymology. Based on the Romanian smântână and Polish smięta$n a$, they support the version that suggests the original for-Slavic smetana; according to this assumption the sound /ę/ was replaced back in the for-Slavic (and in the early times) by the sound /e/ (ECYM 5: 320).

Actually, there are quite convincing objections against the original for-Slavic smetana, as well as the alternative explanations were suggested many years ago: «...The nasal vowel lacks satisfactory motivation in Slavic $<\ldots>$. Polish dialectal smiętana, perhaps, has

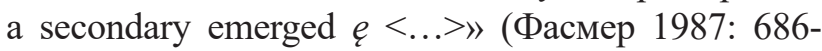
687).

Therefore, this explanation instead of the assumption concerning "the very early" replacement of /ę/ to /e/ in the for-Slavic smętana suggests a more plausible one, i. e., the appearance of non-etymological, secondary nasal vowel /ę/ in the place of the original for-Slavic /e/. Moreover, the Polish smiętana is really a dialectal variant; the Polish norm here is a variant without nasal vowel, smietana (Brukner 1985: 588).

From the semantic point of view (based on the traditional technology of sour cream production and the Slavic parallels) the version of the original for-Slavic *szmetana looks also more convincing. Traditionally the sour cream production presumes that the cream has to be taken off from milk. The Romanian (which has an Istro-Romanian analogy) verb a smântâni (derived from the noun smântână) also means 'to TAKE OFF the sour cream from milk'.

Taking into account that the Romanian smântână could be considered as part of a group of Slavic loanwords with the epenthetic sound /n/ in the Romanian language, it seems all the more correct to prefer the version that in the case of the Romanian smântână we also have the epenthetic sound $/ \mathrm{n} /$.

Thus, we see the quite expressive, albeit relatively few (twelve words), group of Slavic loanwords with epenthetic sound /n/ in the Romanian language, which includes the verb we started from, a cinsti. And, trying to explain all the facts described above, I suppose that both Ukrainian частувати and Polish czestowac appeared independently from each other (that does not exclude the Polish influence on some Ukrainian dialectal variants of частувати), as well as on the Romanian a cinsti.

The Romanian a cinsti (and cinste), as well as the group of Slavic loanwords with epenthetic sound $/ \mathrm{n} /$ in the Romanian language, were a result of early contacts of the Romanian language with some for-Slavic dialect (or dialects), for which this tendency was typical.

We can suppose that some traces of this for-Slavic dialect (dialects) could be found in the Carpathian Ukrainian dialects as well. Perhaps, the Ukrainian dialectal чандрий, мандрици, чендрий (taking into 
account, that the supposed by P. E. Hritsenko Polish source, szczodry - demonstrates the absence of a secondary nasal vowel) is a proper example here, as well as another Ukrainian dialectal form, which exists in the idiom of the Ukrainians of Bulaesti village, / мон'золете / 'to' procrastinate; fiddling around in vain’ (in Russian: ‘мусолить; впустую теребить’).

\section{Note}

${ }^{1}$ The research was supported by the National Program of the Republic of Moldova (2020-2023), project No. 96PS 20.80009.1606.02: Evoluția tradițiilor și procesele etnice în Republica Moldova: suport teoretic și aplicativ în promovarea valorilor etnoculturale şi coeziunii sociale.

\section{References}

Brukner A. Słownik etymologiczny języka polskiego. Warszawa: Wiedza Powszechna, 1985. 808 p.

DEX: Dicționar Explicativ Român Online. https:// dexonline.ro/ (vizited 02.02.2021).

Romanchuk A. A. The early ethnic history of Bulaestian dialect speakers through the issue of asynchronous VN-reflexes in the Ukrainian dialectal continuum. In: Revista de Etnologie si Culturologie, 2017. Vol. XXII, p. 68-71.

ГГ 1997: Гуцульські говірки. Короткий словник. Від. ред. Я. Закревська. Львів: Інститут українознавства ім. І. Крип'якевича, 1997. 232 с. / GG 1997: Gutsul's'ki govirki. Korotkii slovnik. Vid. red. Ia. Zakrevs'ka. L'viv: Institut ukraïnoznavstva im. I. Krip'iakevicha, 1997. 232 s.

Гриценко П. Із спостережень над нетиповими континуантами псл. *е̧ в українських говірках. In: Український діалектний збірник: кн. 3. Під ред. П. Гриценко. Київ: Довіра, 1997, с. 199-210. / Gritsenko P. Iz sposterezhen' nad netipovimi kontinuantami psl. *ȩ v ukraïns'kikh govirkakh. In: Ukraïns'kii dialektnii zbirnik: kn. 3. Pid red. P. Gritsenko. Kiïv: Dovira, 1997, s. 199-210.

ЕСУМ 3: Етимологічний словник української мови. Т. 3. Під ред. О. С. Мельничука. Київ: Наукова думка, 1989. 552 с. / ESUM 3: Etimologichnii slovnik ukraïns'koï movi. T. 3. Pid red. O. S. Mel'nichuka. Kiiv: Naukova dumka, 1989. 552 s.

ЕСУМ 4: Етимологічний словник української мови. Т. 4. Під ред. О. С. Мельничука. Київ: Наукова думка, 2003. 656 с. / ESUM 4: Etimologichnii slovnik ukraïns'koï movi. T. 4. Pid red. O. S. Mel'nichuka. Kiïv: Naukova dumka, 2003. 656 s.

ЕСУМ 5: Етимологічний словник української мови. Т. 5. Під ред. О. С. Мельничука. Київ: Наукова думка, 2006. 703 с. / ESUM 5: Etimologichnii slovnik ukraïns'koï movi. T. 5. Pid red. O. S. Mel'nichuka. Kiiv: Naukova dumka, 2006. 703 s.

ЕСУМ 6: Етимологічний словник української мови. Т. 6. Під ред. О. С. Мельничука. Київ: Наукова думка, 2012. 567 с. / ESUM 6: Etimologichnii slovnik ukraïns'koï movi. T. 6. Pid red. O. S. Mel'nichuka. Kiïv: Naukova dumka, 2012. 567 s.

МРC 1961: Молдавско-русский словарь / Дикционар молдовенеск-русеск. Ред. А. Т. Борщ. Кишинэу: Штиинца, 1961. 780 с. / MRS 1961: Moldavsko-russkii slovar'/ Diktsionar moldovenesk-rusesk. Red. A. T. Borshch. Kishineu: Shtiintsa, 1961. 780 s.

Романчук А. А., Тащи И. Н. Ранняя история украинского села Булаешты в контексте истории Молдовы (XIV - начало XVII вв. от Р. X.). Кишинев: Высшая Антропологическая Школа, 2010. 144 c. / Romanchuk A. A., Tashchi I. N. Ranniaia istoriia ukrainskogo sela Bulaeshty $\mathrm{v}$ kontekste istorii Moldovy (XIV - nachalo XVII vv. ot R. Kh.). Kishinev: Vysshaia Antropologicheskaia Shkola, 2010. 144 s.

СДЕЛМ 1978: Скурт дикционар етимоложик ал лимбий молдовенешть. Ред. Н. Раевский, М. Габинский. Кишинев: Редакция принчипалэ а Енчиклопедией Советиче Молдовенешть, 1978. 680 п. / SDELM 1978: Skurt diktsionar etimolozhik al limbii moldovenesht'. Red. N. Raevskii, M., Gabinskii. Kishinev: Redaktsiia princhipale a, Enchiklopediei Sovetiche Moldovenesht', 1978. 680 p.

СБГ 2005: Словник буковинських говірок. Ред. Н. В. Гуйванюк, К. М. Лук'янюк. Чернівці: Рута, 2005. 688 c. / SBG 2005: Slovnik bukovins'kikh rovipok. Red. N. V. Guivaniuk, K. M. Luk'ianiuk. Chernivtsi: Ruta, 2005. 688 s.

Срезневский И. И. Материалы для словаря древнерусского языка по письменным памятникам. T. 3. Вып. 2 (Т-Я). СПб.: Тип. Имп. Акад. Наук, 1912. 996 c. / Sreznevskii I. I. Materialy dlia slovaria drevnerusskogo iazyka po pis‘mennym pamiatnikam. T 3. Vyp. 2 (T-Ia). SPb.: Tip. Imp. Akad. Nauk, 1912. $996 \mathrm{~s}$.

Фасмер М. Этимологический словарь русского языка. Т. 3. М.: Прогресс, 1987. 832 с. / Fasmer M. Etimologicheskii slovar' russkogo iazyka. T. 3. M.: Progress, 1987. 832 s.

Шевельов Ю. Історична фонологія української мови. Харків: Акта, 2002. 1055 с. / Shevel'ov Iu. Istorichna fonologiia ukraïns 'koï movi. Kharkiv: Akta, 2002. $1055 \mathrm{~s}$.

Alexei Romanciuc (Chișinău, Republica Moldova). Cercetător ştiinţific, Centrul de Etnologie, Institutul Patrimoniului Cultural.

Алексей Романчук (Кишинев, Республика Молдова). Научный сотрудник, Центр этнологии, Институт культурного наследия.

Aleksey Romanchuk (Chisinau, Republic of Moldova). Researcher, Center of Ethnology, Institute of Cultural Heritage.

E-mail: dierevo@mail.ru, dierevo5@gmail.com ORCID: https://orcid.org/0000-0002-2021-7958 